\title{
ORGANIZATION OF RESEARCH AND TRAINING IN AFRICA
}

\begin{abstract}
$\mathrm{T}$ HE international conference on the "Organization of Research and Training in Africa in Relation to the Study, Conservation and Utilization of Natural Resources"' was eonvened by the Director-General of the United Nations Educational, Scientific and Cultural Organization in accordance with a resolution adopted by the General Conference of that Organization, and was held at Lagos during July 28-August 6, 1964. The final report of the conference, now issued by Unesco* in association with the United Nations Economic Commission for Africa, has chapters on national scientific policies from the point of view of research on natural resources; on the preparation and implementation of policies of research on natural resources; on scientific and technical personnel; on finance and research economics; on international co-operation in research on natural resources. It also includes the texts of speeches made at the opening and the closing of the conference. The recommendations adopted are given at the end of each chapter, and the outline of a plan for scientific research and training in Africa, which was agreed in a recommendation, is issued separately and discussed on p. 1141 of this issue of Nature.

The factual chapter on national scientific policies is probably the most realistic, giving concise summaries of the position in the 28 countries reporting. Appended to this chapter there is a brief statement of the imperatives of national science policy. These are listed as: realization by African Governments of the need to estab. lish short- and long-term economic development programmes; recognition of the need to establish scientific research and industrial research programmes, both shortterm and long-term; of their responsibility for organizing scientific research and encouraging research by creating a favourable atmosphere; recognition by scientists of their responsibilities towards their own countries; respect for

* Final Report of the Lagos Conference. (International Conference on the Organization of Research and Training in Africa in Relation to the Study Conservation and Utilization of Natural Resources, Lagos, Nigeria, July 28 to August 6, 1964.) Pp. 102. (Paris: United Nations Educational, Scientific and Cultural Organization, 1964.) 3 francs; 48 .
\end{abstract}

\section{THE SCIENCE AND TECHNOLOGY BILL}

$\mathrm{T}$ HE debate in the House of Lords on February 4 on the Science and Technology Bill was of interest chiefly for some further information given by Lord Champion in moving the second reading. The Science Research Council would take over the present responsibilities of the Department of Scientific and Industrial Research for research grants to universities and postgraduate training awards, including grants for support of applied as well as pure science. Lord Champion said that the chairmanship of this Council, unlike that of the A.gricultural and Medical Research Couneils, would be held by a scientist as a full-time post.

Turning to the Natural Environment Research Council, Lord Champion stated that Sir Graham Sutton had accepted the invitation of the Secretary of State for Education and Science to be chairman of the new Research Couneil. However, Sir Graham would continue to devote most of his time to his responsibilities as director-general of the Meteorological Office, and a secretary of the new academic freedom and the right to free choice of methods and techniques; recognition of the need to establish a proper balance between fundamental and applied research; scientific collaboration at both regional and continental levels; establishment at the highest level of a bodys responsible for elaborating the national scientific policy and co-ordinating research activities; recognition of the need for study and research on natural resources and co-ordination of the activities of the bodies responsible; the necessity of training a sufficient number of research personnel as rapidly as possible and of the essential role of the universities in this respect; recognition of the need to include in all national budgets special provision for scientific and technical research.

The chapter on scientific and technical personnel estimates that the present total of research workers in Africa in natural resources may be some 2,280 , but even a total of 5,000 would not give a ratio of research workers for the total population of more than $1: 50,000$. For the period $1965-80$ a ratio of 200 scientific personnel and university science teachers per million inhabitants is suggested. In this total, experienced postgraduates, university graduates and technicians would be represented in ratios of $1: 3: 2$.

The chapter on international co-operation recognizes that Africa is already receiving considerable assistance in this field from various Governments as well as from the United Nations, the Economic Commission for Africa and the specialized agencies, and it will be necessary to continue to strengthen and co-ordinate these efforts. It also admits that there are gaps in the present scientific structure, insufficient research workers and teachers, and inadequate financial resourees, and that by 1980 some $50,000-70,000$ research workers will be required from some source or other. Nevertheless, there is little appreoiation of what has been done in the past in this field for Africa by individual Governments, or of the impor. tance of ensuring conditions that will facilitate free international co-operation and interchange in any field of scientific endeavour.
Research Council would be appointed who would be a scientist holding appropriate qualifications. The Natural Environment Research Council would not be formally constituted until June, but the Science Research Council, for which the nueleus of a staff already exists in the Department of Scientific and Industrial Research, would be formed on April 1. Meanwhile, the activities of the component organizations under the Natural Environment Research Council would continue without interruptions, and on the dissolution of the Department of Scientific and Industrial Research the responsibility for making research grants to universities and postgraduate training awards in the field of interest to the Natural Environment Research Council would be taken over temporarily by the Science Research Council. Responsibility for the Geological Survey and Museum would be taken over temporarily by the Department of Education and Science.

Lord Champion went on to point out that responsibility for the Atomic Energy Authority had already, by Order 
in Council, been taken over by the Minister of Technology. Under Clause 4 of the Bill the Authority would be able to extend its research functions outside the field of nuclear energy if the Minister of Technology so desired. This would enable the resources of skill, expertise and facilities in the Authority to be made available to support the Ministry in stimulating technological advance in industry if opportunity offered. Viscount Caldecote later suggested that it would be more appropriate to run down any strength not required in the Authority and transfer such highly qualifiod staff elsewhere in industry.

Lord Champion announced that an Order in Council was being laid that day bringing the National Research Development Corporation within the responsibility of the Minister of Technology, and it was hoped to introduce a Bill shortly which would increase the effectiveness of the Corporation. He said that a review was under way to establish the feasibility of orientating purchases and contracts in directions which would aid technological progress, including consideration of purchases made by the authorities directly and indirectly financed from public funds. The Minister of Technology was setting up several technical appraisal teams of scientists, engineers and economists from within and outside the Government service to investigate the performance and products of seetors of industry, to identify any technological weaknesses, and to consider the ways in which these might be remedied. Other methods contemplated were the intensified placing of development contracts with industry, possibly under the supervision of the appropriate research station; steps to improve the supply and status of engineers; action to ensure that in the engineering field the British Standards Institution made the maximum contribution to the objectives of the Ministry. A suggestion from Lord Brown that the universities were themselves mainly responsible for the shortage of technologists and engineers and for failure to expand in this respect was stoutly refuted by Lord Chorley. Lord Snow, agreeing as to the importance of the status of engineers, added that he believed that the use of engineers could be radically improved by constructive action and by attempting to bring into othor parts of industry not used to employing professional skill, the kinds of skill which were already used in the advanced industries.

\section{THE WELLCOME FOUNDATION, LTD.}

T was in 1880 that $\mathrm{H}$. S. Wellcome, an American citizen by birth, came to England to partner S. M. Burroughs, and later to form Burroughs Wellcome and Company. On the death of Burroughs, Wellcome assumed sole control of the Company. His flair for commerce (he pioncered largescale manufacture of tablets, with scientifically precise dosage, under the famous trade-mark 'Tabloid'); his drive, his profound belief in research, and his philanthropic outlook, these qualities combined to make possible the Wellcome Foundation and, later under the terms of his will, the Wellcome Trust, ". . . which applies the profits it receives to the advancement of medical and allied sciences and to the establishment or endowment of research museums and libraries throughout the world". The story of this Foundation, unique alike in character and structure, is well told and lavishly illustrated (much in colour) in a new publication*. It is a document of considerable scientific interest and is well worth reading, especially by those concerned with prevention, control and cure of disease.

Although its headquarters are still in the familiar building in Euston Road, London, the ramifications of the Wellcome Foundation, through its subsidiarios and associated companies, Burroughs Wellcome International, Ltd., and Cooper, MeDougall and Robertson, Ltd., are world wide. The chief operating centres are: Canada, Montreal; United States, New York and Chicago; South America, Rio de Janeiro, São Paulo and Buenos Aires; Europe, Paris, Brussels, Rome, Porrino; Africa, Nairobi, Salisbury and Johannesburg; Asia, Karachi and Bombay; Australia, Sydney; and Now Zealand, Auckland. Prominence is given in this brochure to the Research Laboratories in the United Kingdom at Beckenham, Kent (Langley Court); to the Chemical Works at Dartford, Kent; and to the Veterinary Research Station at Frant, Kent. Many of the products of Cooper, MeDougall and Robertson, Ltd., acquired by the Foundation in 1959, are manufactured in the Kelvindale factory, Glasgow, but the Cooper Technical Bureau is maintained at Berkhamsted, Hertfordshiro, wherein is conducted research on insecticides, parasitic and bacterial diseases of animals, animal nutrition, chemical manufacture and pressure packing. Here, too, is the focus of collecting and recording scientific information. Some illustrated details are also

* The Wellcome Foundation, Ltd. Pp. 52. (London: The Wellcome Foundation, Ltd., 1964.) briefly given of the activities of the Company's overseas houses.

It is, however, when we come to examine some of the many outstanding achievements of the Foundation over the years that the impressive service it has rendered to mankind and animals becomes clearly manifest. As long ago as 1894 it was the first British company to produce diphtheria antitoxin. During 1904-14, Sir Henry Dale, then director of research, discovered and investigated histamine, acetylcholine and sympathomimetic amines, and showed how nerve impulses are transmitted. During 1921 the principles forming the basis of all methods of immunization were outlined. The period 1927-31 witnessed the discovery of diphtheria vaccines A.P.T. and T.A.F., also digoxin ('Lanoxin'); this was when the company introduced dog distemper prophylactics. In 1933 it was ". . . discovered that maternal antibodies in sheep are transferred from ewe to lamb in the first milk. From this have come the present-day methods of protecting lambs against many killing infections". In 1938 came the discovery of the antibacterial effects of sulphones, to-day the chief agents for treating leprosy. Between 1939 and 1949 came the discoveries of globin zinc insulin; the antibiotic polymyxin $B$ ('Aerosporin', 'Thiosporin'); the pharmacology of suxamethonium (succinylcholine), the short-acting muscle relaxant ('Anectine', 'Midarine'); and the issue of the first pure tubocurarine ('Tubarine'), the muscle relaxant for major surgical operations. In the decade 1952-62 were discovered the anti-cancer drug, mercaptopurine ('Puri-nethol'), the antimalarial pyrimethamine ('Daraprim'), the anthelmintic bephenium ('Alcopar', 'Frantin'); and in 1962 azathioprine ('Imuran'), making possible transplantation of kidneys. In 1963 the company introduced methisazone ('Marboran'), the first antiviral chemotherapeutic compound, effective against smallpox.

This is a proud record. It is a remarkable tribute to that "blend of science, business and philanthropy" envisaged by the founder, Sir Henry Wellcome, LL.D., D.Sc., F.R.S., as he was when he died in 1936. In the Truman Wood Lecture to the Royal Society of Arts in 1963, Prof. E. B. Chain said: "Rarely can a contribution from a University laboratory have exceeded in theoretical or practical importance the discoveries which originated in the Wellcome Physiological Research Laboratories" (now part of the Wellcome Research Laboratories). 